\title{
Monitoring of Mercury Content in the Main Environmental Components Caused by Lignite Combustion in Large Thermal Power Plants
}

\author{
DELIA NICA BADEA ${ }^{1 *}$, MIHAELA GABRIELA DUMITRU², IGOR CRETESCU³ \\ ${ }^{1}$ Constantin Brancusi University of Targu Jiu, Faculty of Technical, Medical and Behavioral Sciences, 30 Calea Eroilor, 210135, \\ Targu Jiu, Romania \\ ZUniversity of Craiova, Faculty of Sciences, Department of Chemistry, 107l Calea Bucuresti, 200585, Craiova, Romania \\ ${ }^{3}$ Gheorghe Asachi Technical University of Iasi, Faculty of Chemical Engineering and Environmental Protection, 73 D. Mangeron \\ Blvd., 700050, lasi, Romania
}

\begin{abstract}
The aim of experiment was to evaluate the local impact of mercury accumulations, discharge from coal power plants, by examining samples of ash, slag, soil, spontaneous vegetation and crop plants, using as analytical techniques the cold vapor atomic absorption spectroscopy. Mercury determined in samples of lignite $\left(0.020 \mathrm{mg} . \mathrm{Kg}^{-1}\right)$, is found in flyash samples retained by filters $\left(0.037 \mathrm{mg}^{\mathrm{Kg}}{ }^{1}\right)$, bottom ash transported hydraulic in deposit $\left(0.022 \mathrm{mg} . \mathrm{Kg}^{-1}\right)$, adjacent soils landfill and the power plant $\left(0.12 \mathrm{mg} . \mathrm{Kg}^{-1}\right.$ or 0.049 $m g . \mathrm{Kg}^{1}$ ). The mercury content in vegetation presents differentiated values depending on the bioavailability of plant, area and the positioning of the emission source, reaching values between 0.014 at $0.005 \mathrm{mg} . \mathrm{Kg}^{1}$ in the wild flora and $0.022 \mathrm{mg} . \mathrm{Kg}^{1}$ to $0.004 \mathrm{mg} . \mathrm{Kg}^{1}$ for plants crop. Data obtained for plants, confirmed that most families tend to accumulate mercury plant in larger quantities in the roots $\left(0.022 \pm 0.0016 \mathrm{mg}^{-\mathrm{Kg}^{1}}\right)$ and moderate quantities in the foliar level by translocation or by direct vapor absorption.
\end{abstract}

Keyword: coal combustion, mercury concentration, soil plant accessibility, CVAAS

Mercury is one of heavy metal that is widespread in the environment in many physical and chemical forms: elemental $\mathrm{Hg}\left(\mathrm{Hg}^{0}\right)$, inorganic $\mathrm{Hg}\left(\mathrm{Hg}^{2+}\right)$, associated with ions ( $\left.\mathrm{HgS}, \mathrm{HgCl}_{2}\right)$, mercurous chloride or calomel $\left(\mathrm{Hg}_{2} \mathrm{Cl}_{2}\right)$ and organic $\mathrm{Hg}^{2}$ (e.g., $\mathrm{CH}_{3}-\mathrm{Hg}$ ). There are two main types of reactions which convert the mercury in the mercury cycle through its various forms: oxidation-reduction, and methylation-demethylation. Mercury abundance in the Earth's crust is very low being in the range 0.02 to $0.06 \mathrm{mg}$. $\mathrm{Kg}^{-1}$, although it is likely to be more concentrated in argillaceous sediments and in coal [1]. Concentrations of mercury in soils in the world [2] have the values: UK rural soils $\left(0.07\right.$ to $1.22{\mathrm{mg} . \mathrm{Kg}^{-1}}^{-1}$, mean $\left.0.13 \mathrm{mg} . \mathrm{Kg}^{-1}\right)$; Greek soils $\left(0.033-0.101 \mathrm{mg}^{\mathrm{Kg}}{ }^{-1}\right)$; Peats in Poland $(0.05-1.4 \mathrm{mg}$. $\mathrm{Kg}^{-1}$, mean $\left.0.09 \mathrm{mg} . \mathrm{Kg}^{-1}\right)$; Russian soils - Asia (0.01-0.29 mg. $\mathrm{Kg}^{-1}$, mean $\left.0.08 \mathrm{mg} . \mathrm{Kg}^{-1}\right)$.

Burning coal is the main source of mercury emitted into the environment, burning fossil fuels produces $45 \%$ of the total mercury emitted from human activity worldwide $[3,4]$. The spatial dispersion and deposition level of mercury around coal power plants is non uniform [5] and depends on many factors: the level of emissions, chemical form of mercury emitted, exhaust chimney height, exhaust temperature and weather conditions [6]. The analysis of the products and by-products involved in the processes of energy production from coal is an indispensable tool for controlling and preventing environmental problems caused by mercury emissions. Hg in soils is related mainly with atmospheric deposition [7].

A number of studies have reported that presence and accumulation of $\mathrm{Hg}$ in soils and vegetation around power plants. The soil around power plant has been shown to be rich in Hg: Albufera Mallorca of Spanish (100-150 $\left.\mu \mathrm{g} \mathrm{Kg}^{-1}\right)$, [5]; Baoji Power plant of China $\left(1.000 \mu \mathrm{ug} \mathrm{Kg}^{-1}\right),[6]$ and $2.100 \mu \mathrm{g} . \mathrm{Kg}^{-1}$ in the Serbian Nikola Tesla power plant [7]. The extant computer modeling for this study suggests that increased local deposition will occur on a local (2 to10 $\mathrm{km}$ ) to regional scale ( 20 to $50 \mathrm{~km}$ ) with local increases a small percentage of background deposition on the regional scale.

Mercury is one of the most hazardous contaminants emitted to the atmosphere due to its toxic effects on the environment and human health. Excessive exposure to mercury is associated with a wide range of adverse health effects, including damage to the central nervous system (neurotoxicity), kidney, developing fetus (organic mercury, methylmercury), can cause birth defects and attention deficit hyperactivity disorder [8]. Lethal dose by ingestion (LD50) it is $0.02 . \mathrm{Kg}^{-3}$. Due to these considerations limits have been established for food and medicines by health authorities. Maximum levels (MLs) for mercury, lead, cadmium and tin in foodstuffs (milk, meat, fish, cereals, vegetables, fruit and fruit juices, fish and fish products) have been set by European Comission, [9]. Starting from literature data to estimate the local impact of mercury accumulations was studied local transport of mercury released from coal power stations, by examining samples of ash, slag, soil, vegetation and plants crop, by applying analytical techniques: cold vapor atomic absorption spectroscopy (CVAAS).

\section{Experimental part}

Maerial and methods

The area of Power Plant Turceni, Gorj-Romania is characterized by emphasizing the drainage favored marmo-loose rocks and clay, clays, sands, gravels. The hydrographic network is continuously deepened and widened under the action of tectonic factors, climatic and works. From a climate perspective is influenced mainly Mediterranean climate, with movement of southern and western part, interfering with air circulation in the passageway Jiu, NW-SE direction. Forests and natural vegetation represented by its narrow gradually, giving way to grasslands and crops. 
Monitoring of environmental pollutants include compounds for investigating multiple areas - air, water, soil,vegetation in urban and in rural areas. Soil and plant sampling was conducted on the J iu river corridor, between the localities, Brãne'ti - Ceplea and Ilie'ti J ilu, in the NW-SE direction, considering the relief of the area and the predominant directions of the atmospheric circulation adjacent to the pollution sources (power plant and cinder deposit). The type, number and positioning of the collected samples are shown in figure 1.

The solid samples lignit, bottom ashes, filter ashes, slag and ash deposits, soil were prepared in laboratory for the determination of total mercury content. The samples were crushed and dried at room temperature for $48 \mathrm{~h}$ and passed through a $2 \mathrm{~mm}$ sieve. A portion of $2.5 \mathrm{~g}$ was taken and subjected to mineralization with aqua regia and hydrogen peroxide according to ISO 11466:1999. The sample preparation for thedetermination of mercury solid samples was done according to MA079 Re.0/2006 Microwave Operating Manual, wet mineralization $\mathrm{HNO}_{3}{ }_{3} \mathrm{HCl}$ and $\mathrm{H}_{2} \mathrm{O}_{2}$ using digester Milestone. The digestion solutions were transferred into volumetric flasks of $50 \mathrm{~mL}$ (washing with distilled water filter); $1 \mathrm{~mL}$ of each solution was diluted 1:10 and analyzed by CVAAS.

About $500 \mathrm{~g}$ of each plant species in each sampling locations was collected, put in clean plastic bags and transported to the laboratory. The plant samples were thoroughly segregated, purified and washed with tap water and then with distilled water placed in a ventilated room and were oven dried at $80^{\circ} \mathrm{C}$ to constant weight. The dried samples were ground and a portion of $1.0 \mathrm{~g}$ was subjected to extraction with aqua regia and hydrogen peroxide following the method from ISO 11466:1999. Calcination plant material is ignited by a furnace NABERTHERM, L9/ $11 / B 170$. The extracts thus obtained is dosed by atomic absorption spectrometry for determination of mercury total forms in coal, ash, slag, soil and plants.

The determination of mercury concentration, total forms in lignite used as fuel, solid combustion by product, soil and plant was carried outby Cold Vapor Atomic Absorption Spectroscopy [10] according to standards international with a spectrometer Thermo Electron Model S Series AA SOLAAR, software platform. For the determination of $\mathrm{Hg}$ in soil and plant samples using hydride generator VP Vapour $100 \mathrm{Kit}$, dosing is made directly by atomic absorption spectrometry without heat atomization: it should be reduced from its compounds to elemental stateand transferred to a vapour gas flow, cold vapour technique.

\section{Results and discussions}

Numerous standard procedures for determining traces of mercury in environmental samples using cold vapor atomic absorption spectroscopy method were reviewed and discussed, the differences consist in the method of oxidation and dissolution of mercury [11, 10]. The basic physicochemical parameters, technical characteristics of the Solaar Cookbook: spectrometer and vapour method, are shown in table 1.

Specific data calibration and plotting calibration curves using software connected to high standards spectrometer for analysis of mercury, total forms in samples collected are presented in figure 2. Mercury, total forms, was quantified by CVAAS, the method recommended for the determination of elements in low concentrations (of 0.01

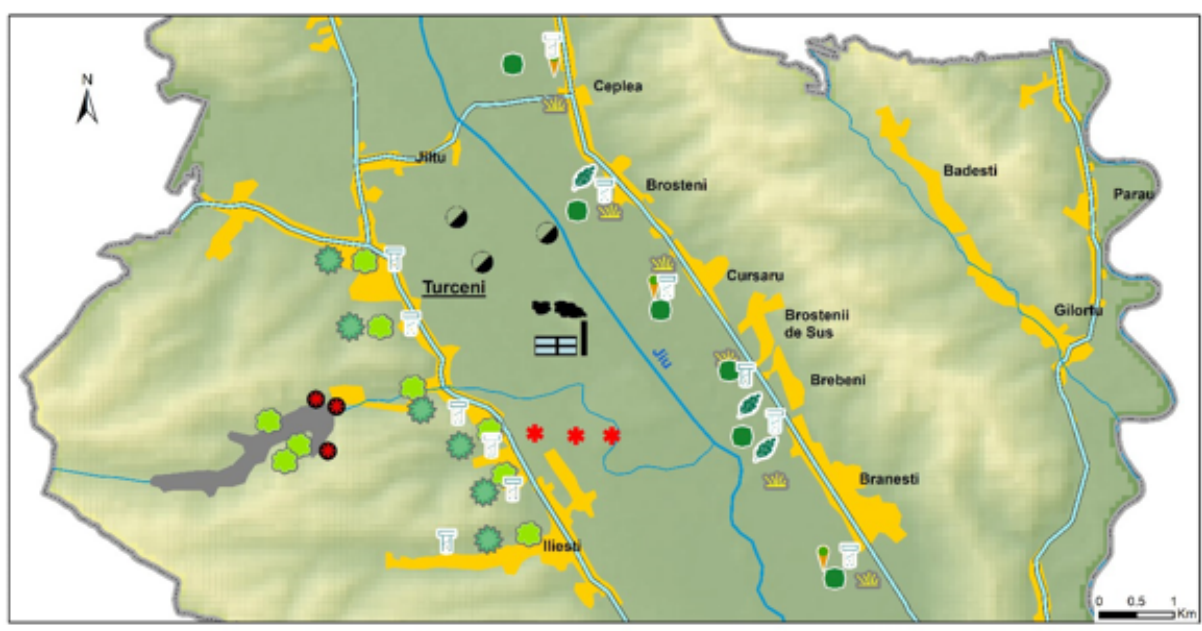

Fig. 2. 1. Map of sampling areas

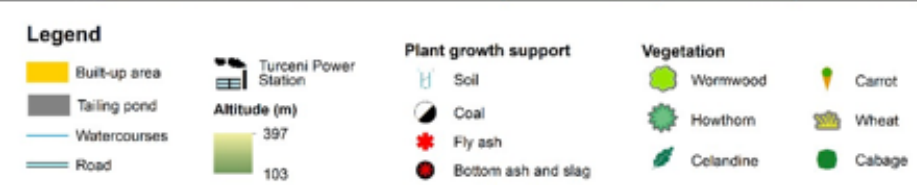

\begin{tabular}{|c|c|c|c|}
\hline \multicolumn{2}{|c|}{ Solaar Cookbook, Spectrometer } & \multicolumn{2}{|c|}{ Solaar Cookbook, Vapour method } \\
\hline Characteristics & Database & Characteristics & Database \\
\hline Primary wavelength & $253.7 \mathrm{~nm}$ & Measurement delay & $40-70$ seconds \\
\hline Bandpass & $0.5 \mathrm{~nm}$ & Carrier gas flow & $50-150 \mathrm{~mL} / \mathrm{min}$ \\
\hline Secondary wavelength & $253.7 \mathrm{~nm}$ & Pump speed & $30-40$ RPM \\
\hline $\begin{array}{l}\text { Flame characteristic } \\
\text { concentration }\end{array}$ & $\begin{array}{l}2.7 \mathrm{mg} / \mathrm{L}: \text { lamp current } \\
75 \% \text {, } \\
\text { normal use }\end{array}$ & Reductant & $\begin{array}{l}0.5 \% \mathrm{~m} / \mathrm{V} \text { sodium } \\
\text { hidroxide, } 0.5-5 \% \\
\mathrm{~m} / \mathrm{V} \mathrm{Sn} \mathrm{Cl}_{2} \text { solution }\end{array}$ \\
\hline $\begin{array}{l}\text { Furnace characteristic } \\
\text { mass }\end{array}$ & $\begin{array}{l}58 \mathrm{pg} \text { : lamp current } \\
75 \% \text {, best sensitivity }\end{array}$ & Acid reagent & $\begin{array}{l}5 \% \mathrm{~V} / \mathrm{V}, 0.5 \mathrm{M} \\
\text { hidrochloric acid }\end{array}$ \\
\hline $\begin{array}{l}\text { Vapour characteristic } \\
\text { concentration }\end{array}$ & $\begin{array}{l}0.2 \mathrm{ug} / \mathrm{L}: \text { lamp curren } \\
75 \% \text {; best precision }\end{array}$ & Sginal & $\begin{array}{l}6 \mathrm{ug} / \mathrm{L} \text { gives about } \\
0.1 \mathrm{~A}\end{array}$ \\
\hline
\end{tabular}

Table 1

TECHNICAL CHARACTERISTICS OF THE SOLAR COOKBOOK 

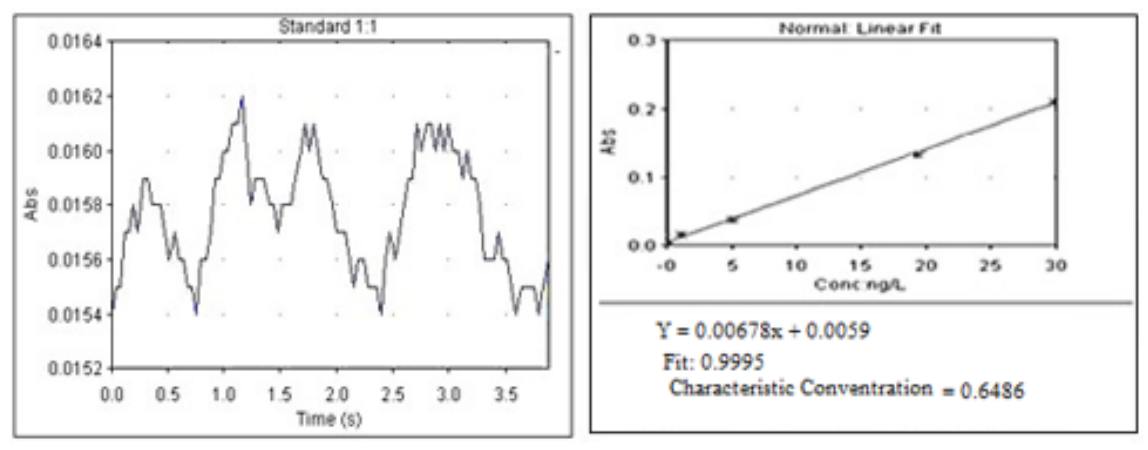

Fig. 2. Mercury calibration signal and calibration graph

\begin{tabular}{|c|c|c|c|c|}
\hline No. & Samples & Area sampling & $\begin{array}{l}\mathrm{Hg}\left(\mathrm{mg} \cdot \mathrm{Kg}^{-1}\right) \\
\text { average } \pm \mathrm{sd}\end{array}$ & $\begin{array}{l}\text { Reporting basis } \\
\mathrm{mg} \cdot \mathrm{Kg}^{-1}\end{array}$ \\
\hline 1 & Coal $(n=3)$ & Coal deposit & $0.020 \pm 0.012$ & 0.01 to $1.0[12]$ \\
\hline 2 & Fly ash $(n=3)$ & Dedusting filters & $0.037 \pm 0.012$ & 0.02 to $2.00[14]$ \\
\hline 3 & $\begin{array}{l}\text { Ash and slag }(n=3) \\
h=020 \mathrm{~cm}\end{array}$ & Ash deposit Ceplea & $0.022 \pm 0.011$ & $\begin{array}{l}\mathrm{NV}: 0.1[13,1] \\
0.06[15] \\
0.07 \text { to } 1.22[2]\end{array}$ \\
\hline 4 & $\begin{array}{l}\text { Soil }(\mathrm{n}=6) \\
\mathrm{h}=0-20 \mathrm{~cm}\end{array}$ & $\begin{array}{l}\text { Border zone } \\
\text { ash deposit } \\
\text { Turceni-Iliești }\end{array}$ & $0.102 \pm 0.054$ & $\begin{array}{l}\text { NV: } 0.1[13,1] \\
0.06[15] \\
0.07 \text { to } 1.22[2]\end{array}$ \\
\hline 5 & $\begin{array}{l}\text { Soil }(\mathrm{n}=6) \\
\mathrm{h}=0-20 \mathrm{~cm}\end{array}$ & $\begin{array}{l}\text { Neighboring power plant: } \\
\text { Brănești-Ceplea }\end{array}$ & $0.049 \pm 0.013$ & $\begin{array}{l}\mathrm{NV}: 0.1[13,1] \\
0.06[15] \\
0.07 \text { to } 1.22[2]\end{array}$ \\
\hline 6 & $\begin{array}{l}\text { Wormwood leaves- } \\
\text { flowers }(n=3)\end{array}$ & Ash deposit Ceplea & $0.014 \pm 0.010$ & $\begin{array}{l}0.10[17,18] \\
0.020[19] \\
0.5[20]\end{array}$ \\
\hline 7 & $\begin{array}{l}\text { Wormwood leaves- } \\
\text { flowers }(n=6)\end{array}$ & $\begin{array}{l}\text { Border ash deposit Ceplea, } \\
\text { Turceni-Iliești }\end{array}$ & $0.005 \pm 0.001$ & $\begin{array}{l}0.10[19,17,18] \\
0.020[19] \\
0.5[20]\end{array}$ \\
\hline 8 & Hawthorn fruit $(n=6)$ & $\begin{array}{l}\text { Border ash deposit } \\
\text { Turceni-Iliești }\end{array}$ & $0.012 \pm 0.0018$ & $\begin{array}{l}0.10[19,17,18] \\
0.020[19] \\
0.5[20]\end{array}$ \\
\hline 10 & Celandine $(\mathrm{n}=3)$ & Brănești-Ceplea & $0.004 \pm 0.0012$ & $\begin{array}{l}0.10[19,17,18] \\
0.020[19] \\
0.5[20]\end{array}$ \\
\hline \multirow[t]{2}{*}{11} & Carrot $(n=3)$ & Brănești - Ceplea & $0.022 \pm 0.0016$ & $\begin{array}{l}0.003-0.01[21] \\
0.009-0.048[22] \\
0.020[20]\end{array}$ \\
\hline & Cabbage $(n=4)$ & Brănești - Ceplea & $0.006 \pm 0.0011$ & $\begin{array}{l}0.003-0.01[21] \\
0.009-0.048[22] \\
0.020[19]\end{array}$ \\
\hline 13 & Wheat $(n=4)$ & Brănești-Ceplea & $0.005 \pm 0.0011$ & $\begin{array}{l}0.003-0.01[21] \\
0.009-0.048[22] \\
0.020[19]\end{array}$ \\
\hline
\end{tabular}

Table 2

CONCENTRATION LEVELS OF MERCURY IN SAMPLES (TOTAL FORMS) to $0.2 \mathrm{ng} \cdot \mathrm{mL}^{-1}$ ), calibration curve was linear in the concentration range 0 at $30 \mathrm{ng}^{-1} \mathrm{~L}^{-1}$, regression coefficient is 0.9995 , covering the range of 0.9 at $1.0 \%$ RSD, standard deviation value varied from 0.0001 to 0.00022 .

Analyzing the mercury content, total forms of samples (table 2), it is noted that mercury and its compounds it is found in varying concentrations in the chain of accumulation: lignite, ash and slag, soil and vegetation spontaneous or cultivated, in areas adjacent to the power plant: the localities Brãne'ti - Ceplea and Ilie'ti - Jilu, in the NW-SE direction. The average concentration determined in lignite used as fuel mean value of $0.020 \mathrm{mg}^{\mathrm{Kg}} \mathrm{K}^{-1}$, is at a low level, relative to the concentrations worldwide reported, ranging from 0.01 to $1.00 \mathrm{mg} . \mathrm{Kg}^{-1}$ [12]. Fly ash, average concentration, collected by dust extraction filters is estimated at $0.037 \mathrm{mg} . \mathrm{Kg}^{-1}$. The ash and slag deposit, has an average mercury concentration of $0.020 \mathrm{mg} \cdot \mathrm{Kg}^{-1}$, being shipped in a mixture with water from J iu River, which crosses many zones of mining and processing of the coal. Analyzing the data listed, is noted that, the mercury content in bottom ash, filters ash, ash and slag deposit, do not exceed the normal soils content $\left(0.1 \mathrm{mg} \cdot \mathrm{Kg}^{-1}\right)$, or alert values from sensitive soils ( $\left.1.00 \mathrm{mg} . \mathrm{Kg}^{-1}\right)$, provided by national standards [13]. The determined values for mercury in fly ash $\left(0.037 \mathrm{mg} . \mathrm{Kg}^{-1}\right)$ is at minimum emission values relative to emissions by combustion in a Spanish fluidized bed combustion plant $\left(0.02\right.$ to $\left.2.00 \mathrm{mg} . \mathrm{Kg}^{-1}\right)$ [14].

The dynamics between the amount of mercury, which exist in soil, and its adoption by the plant is non-linear and depends on several variables: cation exchange capacity, soil $p H$, soil ventilation, as well as plant species. Soil samples taken at the base southeast of the deposit of ash and slag (Locality: Turceni - Iliesti), have recorded values of $0.102 \pm 0.054 \mathrm{mg} . \mathrm{Kg}^{-1}$, concentrations above the normal levels of mercury [13]. But these concentrations are situated in the range 0.07 to $1.22 \mathrm{mg} . \mathrm{Kg}^{-1}$ for soils in rural 
areas reported by the UK Environment Agency [2] and exceeding the limit of $0.06 \mathrm{mg}_{\mathrm{Kg}}{ }^{-1}$, reported by Lee Susan (1990) [15]. Concentrations of mercury in soil samples, collected in the direction of propagation of atmospheric emissions (Locality: Branesti - Ceplea), with values of $0.049 \pm 0.013 \mathrm{mg}^{\mathrm{Kg}}{ }^{-1}$, are located well below the normal value of national rules butvery near the limit of $0.06 \mathrm{mg} . \mathrm{Kg}$ ${ }^{1}$, reported in the literature for dry and uncontaminated soils [15] or mercury abundance in the Earth's crust [1].

The mercury may enter into the structure of the plant by two main ways: 1) the absorption of the oxidized form of $\mathrm{Hg}$ (II) or methyl-mercury adsorbed on soil particles and / or dissolved in ground water by roots; 2) absorption of $\mathrm{Hg}^{0}$ vapor in the atmosphere through stomata, or derived from volatilization of mercury from the mercury-rich soil surface. Route 1 is specific to plant roots, lane 2 is a characteristic of foliage segment of the plants [16]. Therefore, spontaneous flora, plants grown inside deposit of ash and slag accumulated mercury at a concentration of 0.014 mg.Kg-1 for wormwood. Spontaneous vegetation around the deposit (Locality: Ilie'ti - Jilu ) accumulated mercury in concentrations of $0.012 \mathrm{mg}_{\mathrm{Kg}} \mathrm{K}^{-1}$ for haw thorn fruit and $0.005 \mathrm{mg} \mathrm{Kg}^{-1}$ for wormw $00 \mathrm{~d}$, while on the east side of the power plant (Branesti-Ceplea) samples celandine values are $0.004 \mathrm{mg} \cdot \mathrm{Kg}^{-1}$. These plants from spontaneous flora are classified as medicinal herbs whose permissible concentration limits are set to $0.1 \mathrm{mg} \mathrm{Kg}^{-1}[17,18], 0.020$ mg.Kg-1 EC 396/2005 [19] and the value of $0.5 \mathrm{mg}^{-1} \mathrm{Kg}^{-1}$ in Brazil medicinal herbs [20]. Samples of plants grown from the area of influence of the thermal power plant emissions (Locality: Branesti-Ceplea), highlights mercury values of $0.022 \mathrm{mg} . \mathrm{Kg}^{-1}$ for carrot - root, $0.006 \mathrm{mg}_{\mathrm{Kg}}{ }^{-1}$ for cabbage and $0.005 \mathrm{mg} . \mathrm{Kg}^{-1}$ for wheat. The samples concentration of carrot root $\left(0.022 \pm 0.0016 \mathrm{mg} . \mathrm{Kg}^{-1}\right)$ exceeding the concentration of mercury in plants reported by European Comission $\left(0.02 \mathrm{mg}_{\mathrm{Kg}} \mathrm{g}^{-1}\right)$, [ 19]. The obtained data ranged between 0.022 and $0.006 \mathrm{mg} \mathrm{Kg}^{-1}$, detected in crop plants (carrot root, cabbage and wheat), can be found in concentration ranges determined by a number of agro food products research: ranged between 0.003 and $0.01 \mathrm{mg} . \mathrm{Kg}$ ${ }^{1}$ [21]; between 0.009 and $0.048 \mathrm{mg} . \mathrm{Kg}^{-1}$ [22].

Data obtained in this study, on the concentrations of total mercury accumulated in the plants of spontaneous or locally grown under the influence of the coal power plant emissions, confirmed the data reported in the literature, that most plant families tend to accumulate mercury in larger quantities in the roots [1,2] and moderate quantities in the foliar segment by translocation or by direct vapor absorption.

\section{Conclusions}

Burning coal in power plants is the main source of anthropogenic mercury emitted

environment. Mercury is recognized as a global contaminant, because it can be transported at local level $(2-10 \mathrm{Km})$, regional $(20-50 \mathrm{Km})$ and at long distances in the atmosphere, is persistent in the environment, accumulate in the food chain soil-plant-animal-food. Cold vapor techniques atomic absorption spectrometry is much more sensitive, reaching mercury detection limits as low 0.01 to $0.2 \mathrm{ng} \cdot \mathrm{mL}^{-1}$.

The performance of analytical method (CVAAS) applied in this study, permit the mercury detection in all the analyzed samples from local environment with values between 0.004 to $0.12 \mathrm{mg} \mathrm{Kg}^{-1}$. Analyzing mercury content as total forms, confirm the presence of both mercury and its compounds in the distribution chain and accumulation: lignite, ash and slag, soil and spontaneous or cultivated vegetation in the power plant area of influence, slag and ash deposit on the flanks of Jiiu river corridor, between Branesti-Ceplea and Turceni- Ilie'ti localities situated in NW-SE direction.

The xenobiotic heavy metals such as: mercury, cadmium, lead, released from the matrix of coal distributed in space, are considered persistent pollutants, being characterised by high residence times (thousands of years), having the tendency for hyper-accumulation and concentration in soil, plants and animals, leading to harmful effects toward the human organism, considered the final consumer of the food chain soil-plant-animal-food.

\section{References}

1. KABATA-PENDIAS, A., \& MUKHERJEE, A.B., Trace Elements from Soil to Human, Springer-Verlag, Berlin/Heidelberg/New York, 2007, p. 9.

2. ROSS, S.M., WOOD, M.D., COPPLESTONE, D., WARRINER, M., and CROOK, P., Environmental concentrations of heavy metals in UK soil and herbage. [In]: UK Soil and Herbage Pollutant Survey, UKSHS Report No.7/2007, Environment Agency, 2007, p. 60.

3. TUCALIUC, O.M., CRETESCU, I., NEMTOI, G., BREABAN, I.G., SOREANU, G., IANCU, O.G., EEMJ, 13(8), 2014, p. 2051.

4. PACYNA, E.G., PACYNA, J.M., SUNDSETH, K., MUNTHE, J ., KINDBOM, K., WILSON, S., STEENHUISEN, F., MAXSON P., Atmos. Environ., 44, 2010, p. 2487.

5. RODRÍGUEZ MARTÍN, J .A., CARBONELL, G., NANOS, N., GUTIÉRREZ, C., Arch. Environ. Con. Tox., 2013, 6, p. 4171.

6. YANG, X., WANG, L., Environ. Geol., 2008, 53, p. 1381.

7. DRAGOVIC, S., CUJ IC, M., SLAVKOVIC-BESKOSKI, L., GAJIC, B., BAJAT, B. KILIBARDA, M., ONJIA, A., Catena, 104(0), 2013, p. 288. doi:10.1016/j catena.2012.12.004

8. BOUCHER, O., JACOBSON, S.W., PLUSQUELLEC, P., DEWAILLY, É., AYOTTE, P., FORGET-DUBOIS, N., JACOBSON, J. L. AND MUCKLE G., Environ. Health Perspect., 120, 2012, p.1456.

9. EUROPEAN COMISSION, Commission Regulation EC No 1881/2006, Setting maximum levels for certain contaminants in foodstuffs, Off. J. Eur. Union, L 364, 2006, p.5.

10. PFEIL, D., Spectroscopy, 26 (9), 2011, p. 40.

11. PAVLISH, J.H., SONDREAL, E.A., MANN, M.D., OLSON, E.S., GALBREATH, D K.C., LAUDAL, L., BENSON, S.A., Fuel. Process. Technol., , 82, 2003, p. 89.

12. YUDOVICH, Y.E., KETRIS, M.P., Int. J. Coal Geol., 62, 2005, p. 107. 13. *** M.O. Ministry Order No756/1997, for approval of Regulation concerning environmental pollution assessment, Official Gazette of Romania, I Part, No. 303, Bucharest 1997.

14. LOPEZ-ANTON, M.A., DIAZ-SOMOANO, M., DIAZ, L, MARTINEZTARAZONA, M.R., Energ. Fuels, , 25, 2011, p. 3002.

15. LEE SUSAN, M., Metals in foods. A literature survey, No. 12, The British Food Manufacturing Industries Research Association, Surrey, UK 1990.

16. FRESCHOLTZ, T.F., GUSTIN, M.S., SCHORRAN, D.E., FERNANDEZ, C.J., Environ. Toxicol. Chem., 22, 2003, p. 2114.

17. ALLOWAY, B. J., The General Monograph Herbal Drugs (1433). Pharmeur., 20 (2), 2008, p. 302.

18. GASSER, U., KLIER, B., KUHN, A.V., STEINHOFF, B., Pharmeur. Sci. Notes., 1, 2009, p. 37.

19. EUROPEAN COMISSION. Commission Regulation EC No 396/2005 amending Council Directive 91/414/EEC). On maximum residue levels in or on food and feed of plant and animal origi, Off. J. Eur. Union, , 48 (L070), 2005, p. 1.

20. CALDAS, E.D., MACHADO, L.L., Food Chem.Toxicol., 42, 2004, p. 599.

21. ABBAS, M., PARVEEN, Z., IQBAL, M., IQBAL, S., AHMED, M., BHUTTO, R., J. Sci. Engin.Technol., 6 (2), p. 60.

22. MOHAMED, H..H. ALI; KHAIRIA, M. AL-QAHTANI, Egypt. J. Aquat. Res., 38, 2012, p. 31.

\section{Manuscript received: 21.06 .2017}

